\title{
IMPLIKASI PRINSIP EKONOMI SYARI'AH DALAM PENYUSUNAN AKAD QARDH PADA KELOMPOK PEMODAL 13 KEC. PONTIANAK TIMUR
}

\author{
Oleh : \\ Hijrah Wahyudi \\ STIE Indonesia Pontianak \\ Mardiyati \\ STIE Pontianak
}

\begin{abstract}
Purpose of this research is to know implication of syari'ah principle in qardh's contract arrangement in Kelompok Pemodal 13 Kec.Pontianak Timur. To answer purpose of the research is done by qualitative analysis. This research done to members and managements Kelompok Pemodal 13 Kec. Pontianak Timur, where drawdown of sample is done with technique convenience sampling.
\end{abstract}

Based on result of qualitative analysis indicates that eight syari'ah principle in qardh's contract arrangement: independence and open system contract, equality, justice, consensuak, honesty and truth, benefit, and trusteeship. $=$

Keyword: syari'ah principle, qardh contract, Kelompok Pemodal 13 Kec. Pontianak Timur

\section{Pendahuluan}

Kelompok Pemodal 13 merupakan perkumpulan muslimin berkedudukan di Kecamatan Pontianak Timur yang secara rutin (setiap bulan) mengumpulkan sejumlah dana serta menyalurkan dana tersebut dalam bentuk pinjaman tanpa riba (qardh) dan investasi bagi hasil (mudharabah) berbasis syariah. Kegiatan pengumpulan dan penyaluran dana tersebut sudah berlangsung hampir 2 (dua) tahun.

Pengumpulan dana dari anggota (shahibul maal) Kelompok Pemodal 13 dicatat dalam bentuk Modal Titipan (Wadi'ah Yad adh-dhamanah), sedangkan penyaluran dana dicatat dalam bentuk utang-piutang (Qardh) dan investasi (Mudharabah). Kelompok Pemodal 13 mempunyai 20 shahibul maal yang secara rutin setiap bulan menitipkan dana mereka dengan nominal minimal Rp 100.000,-.

Dalam kegiatannya, Kelompok Pemodal 13 bertindak selaku pengelola yang mewakili shahibul maal. Syariat Islam mengatur transaksitransaksi yang sifatnya tidak tunai untuk dicatat dengan tujuan agar tidak terjadi perselisihan di masa yang akan datang antara pihak-pihak yang bertransaksi. Pencatatan itulah yang akan dituangkan ke dalam perjanjian yang disebut dengan akad.

\section{Tinjauan Pustaka}

Menurut Wangsawidjaja (2012) secara etimologi, al 'Aqd berarti perjanjian, perikatan, dan pemufakatan. Dalam pandangan para ahli hukum Islam, janji tidak hanya mengikat secara moral tetapi juga secara hukum apabila dikaitkan dengan suatu sebab, baik sebab itu disebutkan dalam pernyataan janji itu sendiri atau tidak disebutkan.

Zuhaili (1999) menyatakan bahwa secara bahasa, akad adalah ikatan antara dua hal, baik ikatan secara nyata maupun ikatan secara maknawi, dari satu segi maupun dua segi.

Menurut istilah para ahli hukum Islam, akad diartikan sebagai hubungan antara ijab dan kabul sesuai dengan kehendak syariat yang menetapkan adanya pengaruh atau akibat hukum pada objek perikatan.

DSN dalam fatwanya No.45/DSNMUI/II/2005 mengartikan akad sebagai transaksi atau perjanjian syar'i yang menimbulkan hak dan kewajiban.

Dapat disimpulkan bahwa akad merupakan kesepakatan para pihak untuk mengikatkan diri tentang suatu perbuatan hukum tertentu yang akan dilakukan sesuai dengan prinsip syariah. 


\section{Rukun Akad}

Dikutip dalam Djamil (2001) menurut ahli-ahli hukum Islam Kontemporer dan jumhur ulama, rukun yang membentuk akad itu ada 4 (empat), yaitu:

a. Adanya para pihak yang membuat akad.

b. Pernyataan kehendak para pihak untuk mengikatkan diri.

c. Objek akad.

d. Tujuan akad. Masadi (2002) menyatakan bahwa secara umum syarat sahnya suatu akad adalah:

a. Rukun pertama, yaitu adanya para pihak yang harus memenuhi syarat kecakapan untuk melakukan akad atau karena kewenangan atau karena perwakilan.

b. Rukun kedua, berupa pernyataan kehendak para pihak harus memenuhi syarat, yaitu adanya ijab dan kabul yang merupakan kesepakatan para pihak.

c. Rukun ketiga, yaitu mengenai objek akad haus memenuhi syarat, harus telah ada ketika akad berlangsung, daapt ditransaksikan, dapat diserahterimakan, harus jelas, dan diketahui oleh para pihak, harus suci dan tidak najis.

d. Rukun keempat, berupa tujuan akad harus diizinkan oleh syara' atau tidak bertentangan dengannya.

\section{Asas-asas Akad}

Asas Kebebasan dan Sistem Terbuka Hukum Perjanjian; pihak-pihak yang melakukan akad mempunyai kebebasan untuk membuat perjanjian, baik dari segi yang diperjanjikan, maupun dalam menentukan persyaratan-persyaratan lain, termasuk menetapkan cara-cara penyelesaian bila terjadi sengketa. Kebebasan menentukan persyaratan ini dibenarkan selama tidak bertentangan dengan ketentuan syariah Islam. Asas ini bertujuan untuk menjaga agar klausul-klausul yang dicantumkan dalam akad yang dibuat oleh para pihak tidak menimbulkan kedzaliman, paksaan/tekanan, dan penipuan kepada salah satu pihak dalam akad. Apabila terdapat unsur-unsur tersebut dalam akad, maka legalitas akad dianggap meragukan, bahkan tidak sah.

Asas Persamaan atau Kesetaraan; asas ini memberikan kedudukan yang sama kepada para pihak. Karena itu, dalam menyusun suatu akad atau perjanjian, masing-masing pihak dapat mengajukan klausul-klausul menyangkut hak dan kewaijban mereka atas dasar asas kesetaraan ini. Konsep syariah juga menempatkan aspek keseimbangan dunis dan akhirat sebagai salah satu dasar dalam pembangunan sistem ekonomi. Asas ini menghendaki kedua belah pihak memenuhi dan melaksanakan perjanjian. Kreditur mempunyai kekuatan untuk menuntut prestasi dan jika diperlukan dapat menuntut pelunasan prestasi melalui kekayaan debitur, namun debitur memikul pula kewajiban untuk melaksanakan perjanjian itu dengan itikad baik.

Asas Keadilan; keadilan dalam Islam adalah menempatkan sesuatu hanya pada tempatnya dan memberikan sesuatu hanya pada yang berhak serta memperlakukan sesuatu sesuai posisinya. ALLOH memerintahkan manusia agar berbuat adil dalam menetapkan hukum. Para pihak yang melakukan akad dituntut untuk berlaku benar dalam mengungkapkan kehendak dan keadaan, memenuhi perjanjian yang telah mereka buat, dan memenuhi semua kewajibannya. Agar terhindar dari berbuat dzalim, para pihak harus menghindari semua bentuk pemaksaan, tekanan, dan penipuan dalam akad dan pelaksanaan akad yang dibuat. Adanya unsur-unsur tersebut di dalam akad yang dibuat para pihak, dapat mengakibatkan legalitas perjanjian yang dilakukannya tidak sah sehingga dapat dimintakan pembatalan.

Asas Konsensual; asas ini menyatakan bahwa segala transaksi yang dilakukan harus atas dasar kerelaan masing-masing pihak. Kerelaan pihakpihak yang berakad adalah syarat bagi terwujudnya semua transaksi. Jika dalam transaksi tidak terpenuhi asas ini, sama artinya dengan memakan sesuatu dengan cara yang batil. Asas ini mengharuskan ketidakadaan paksaan dalam proses transaksi dari pihak manapun. Kondisi rida ini diimplementasikan dalam perjanjian yang diantaranya dilakukan dengan kesepakatan dalam bentuk ijab dan kabul serta adanya konsep opsi.

Asas Kejujuran dan Kebenaran; ajaran Islam dengan tegas mealrang semua bentuk kebohongan dan penipuan. ALLOH memerintahkan kepada seluruh umat muslim untuk berlaku jujur dalam segala urusan dan perkataan. Apabila asas ini tidak dijalankan, maka akan merusak legalitas akad yang dibuat. Dimana pihak yang meraas dirugikan karena pada saat perjanjian dilakukan pihak lainnya tidak mendasarkan pada asas kejujuran adn kebenaran, dapat menghentikan proses perjanjian tersebut.

Asas Tertulis; asas yang tidak kalah penting dalam bermuamalah tidak secara tunai adalah 
dibuatnya akad secara tertulis, ada saksi, dibacakan, dan adanya agunan. Asas ini penting karena merupakan asas dari prinsip kehati-hatian dan hukum pembuktian dalam bermuamalah atau keperdataan.

Asas Kemaslahatan; hakikat kemaslahatan dalam Islam adalah segala bentuk kebaikan dan manfaat yang berdimensi integral duniawi dan ukhrawi, materil dan spiritual, serta individual dan kolektif. Sesuatu dipandang Islam bermaslahat jika memenuhi dua unsur, yakni kepatuhan syariah (halal) dan bermanfaat serta membawa kebaikan (toyib).

Asas Amanah; dengan asas ini, masing-masing pihak haruslah beritikad baik dalam bertransaksi dengan pihak lainnya dan tidak dibenarkan salah satu pihak mengeksploitasi ketidaktahuan mitranya.

(Anwar:2007)

\section{Komposisi Akad Baku (Standar Kontrak)}

Dikutip dalam Wangsawidjaja (2012) bahwa Akad Baku atau Standar Kontrak mempunyai komposisi sebagai berikut:

1. Judul Akad

2. Komparisi

3. Isi Akad, yang tersusun atas:

a. Jumlah objek yang akan disepakati

b. Jangka waktu

c. Imbalan

d. Penyelesaian perselisihan

e. Representasi dan Jaminan

f. Kewajiban-kewajiban penerima fasilitas

g. Hal-hal yang tidak boleh dilakukan oleh penerima fasilitas

h. Agunan

i. Pemberian kuasa

j. Hak-hak pemilik fasilitas

k. Penyelesaian perselisihan

1. Lain-lain.

\section{Identifikasi dan Perumusan Masalah Penelitian}

Berdasarkan deskripsi tersebut, maka dapat dibuat rumusan masalah sebagai berikut :

"Penyusunan akad qardh (utang-piutang) pada Kelompok Pemodal 13 Kec. Pontianak Timur."

\section{Tujuan Penelitian}

Adapun tujuan dari penelitian ini adalah :

a. Untuk memperkaya pengetahuan pengelola dan shahibul maal (anggota) Kelompok Pemodal 13 Kec. Pontianak Timur mengenai proses penyusunan akad qardh.

b. Untuk mengenalkan dan menambah penguasaan pengelola dan shahibul maal (anggota) Kelompok Pemodal 13 Kec. Pontianak Timur terhadap penyusunan akad qardh.

\section{Manfaat Penelitian}

Dengan adanya penelitian ini, diharapkan pengelola dan shahibul maal (anggota) mampu :

a. Membuat akad qardh (utang-piutang) sesuai dengan syariah.

b. Meningkatkan kemampuan dalam mengoperasian asas-asas akad qardh.

\section{Hasil Penelitian}

\section{Judul Akad}

Judul akad mencerminkan secara umum materi yang diatur dalam suatu akad yaitu Qardh, maka judul akad yang digunakan oleh Kelompok Pemodal 13 Kec. Pontianak Timur yaitu: Akad Qardh.

\section{Komparisi}

Yaitu bagian akad yang memuat keterangan tentang orang, dasar hukum memberikan kewenangan yuridis para pihak, dan kedudukan para pihak berupa pembuatan perjanjian atau akad tersebut

Isi Akad, yang tersusun atas:

$\checkmark$ Jumlah objek yang akan disepakati, berupa utang-piutang dan atau investasi

$\checkmark$ Jangka waktu

$\checkmark$ Imbalan, hanya untuk akad mudharabah

$\checkmark$ Penyelesaian perselisihan

$\checkmark$ Kewajiban-kewajiban penerima fasilitas

$\checkmark$ Penyelesaian perselisihan 


\section{TALIM AHAD}

\section{(1) \\ POKDAL 13

\section{AKAD QARDH (PINJAMAN) \\ No..../AKAD-POKDAL13/.../...}

\section{Bismillahirrahmanirrahim}

Pada hari ini, ...tanggal ...bulan ... tahun ...H yang bertepatan dengan tanggal ...bulan ...tahun ...M, hadir untuk melakukan perikatan qardh:

1. ...bertempat tinggal di ...dalam hal ini bertindak dan atas nama Kelompok Pemodal 13 selaku Ketua, untuk selanjutnya disebut Pihak Pertama.

2. ..., bertempat tinggal di ...dalam hal ini bertindak dan atas nama sendiri selaku peminjam, untuk selanjutnya disebut Pihak Kedua.

Pihak Pertama menerangkan dengan ini meminjamkan kepada Pihak Kedua dan Pihak Kedua menerangkan dengan ini meminjam dari Pihak Pertama dana sebesar $\underline{\mathrm{Rp}}$..., - (...rupiah).

Adapun penyelesaian perikatan qardh ini disepakati secara angsuran ... kali $\mathrm{Rp}$...,- terhitung mulai ....

Apabila dalam pelaksanaan perjanjian ini terjadi permasalahan atau perselisihan, maka kedua belah pihak setuju menyelesaikannya dengan cara musyawarah untuk mufakat.

Demikian perikatan qardh ini dilakukan dengan itikad baik dan tanpa paksaan yang disaksikan oleh:

1.

2. ....

Pihak Pertama,

Saksi 1

Akad qardh tersebut dibuat dua rangkap yang dilengkapi dengan materai cukup.

\section{Kesimpulan}

Dari hasil penelitian, maka diharapkan pengelola dan shahibul maal Kelompok Pemodal $13 \mathrm{Kec}$. Pontianak Timur mampu menyusun akad dengan cara yang tepat sesuai syariah.

\section{Saran}

Ketika umat muslim melakukan transaksi secara tidak tunai, sebaiknya umat muslim mencatatnya
Pihak Kedua,

Saksi 2

dengan menghadirkan dua orang saksi laki-laki serta menuangkannya ke dalam akad.

\section{Daftar Pustaka}

Wangsawidjaja Z, A, 2012, Pembiayaan Bank Syariah, Penerbit PT Gramedia Pustaka Utama, Jakarta.

Anwar, Syamsul, 2007, Hukum Perjanjian Syariah, Studi Tentang Teori Akad Dalam Fikih Muamalat, PT Raja Grafindo Persada, Jakarta.

Dewan Syariah Nasional-MUI-Bank Indonesia, 2006, Himpunan Fatwa Dewan Syariah Nasional, Jakarta. 
Djamil, Fathurrachman, 2001, Sandera Badan terhadap Debitur Menurut Hukum Islam, Jakarta.

Masadi, Ghufron A, 2002, Fikih Muamalah Kontekstual, PT Raja Grafindo Persada, Jakarta.

Zuhaili, Wahbah, 1999, Al Fikih al Islam wa Adilatuh, Kapita Selekta, Jakarta. 